\title{
ОСОБЛИВОСТІ ЗАСТОСУВАННЯ ЗАПОБІЖНОГО ЗАХОДУ ЩОДО НЕПОВНОЛІТНЬОГО ПІДОЗРЮВАНОГО, ОБВИНУВАЧЕНОГО КРІЗЬ ПРИЗМУ КРИТЕРІЇВ ДОЦІЛЬНОСТІ ТА ЕФЕКТИВНОСТІ
}

\author{
Фоміна Т. Г., Романюк В. В.
}

\section{ВСТУП}

Законодавець не без причини передбачив, що досудове розслідування та судовий розгляд щодо неповнолітніх осіб, які вчинили кримінальне правопорушення, відбувається в особливій формі. Такий факт зумовлено психологічними, фізіологічними та психічними особливостями підлітка, який переступив межу закону. Порядок здійснення кримінального провадження щодо цієї категорії осіб визначено в окремій главі 38 КПК України, де і розкрито певні особливості застосування запобіжних заходів до неповнолітніх підозрюваних, обвинувачених.

Відповідно до ст. 493 КПК України до неповнолітніх підозрюваних, обвинувачених можуть застосовуватися як загальні запобіжні заходи (особисте зобов'язання, особиста порука, застава, домашній арешт, тримання під вартою, затримання як тимчасовий запобіжний захід), так i спеціальний (передання під нагляд). 3 огляду на той факт, що правова сутність запобіжних заходів доволі повно вивчена на науковому рівні, у цій роботі нами буде зроблено акцент на 3'ясуванні ефективності та доцільності застосування того чи іншого виду запобіжного заходу, який може бути обрано щодо неповнолітньої особи. Для більш повного розуміння предмета дослідження, слід з'ясувати етимологію таких критеріїв, як «доцільність» та «ефективність». Термін «доцільний» подається як «відповідний поставленій меті, практично корисний, розумний» ${ }^{1}$. Дефініція «ефективний» тлумачиться так: «який приводить до потрібних результатів, наслідків, дає найбільший ефект; який викликає ефект ${ }^{2}$. Отже, розглядаючи питання доцільності обрання запобіжного заходу щодо неповнолітнього, слід виходити із такого. По-перше, чи відповідатиме застосування певного виду запобіжного заходу поставленій меті (тобто чи допоможе запобігти спробам неповнолітнього переховуватися від органів досудового розслідування та

\footnotetext{
${ }^{1}$ Словник української мови: в 11 т. / АН УРСР, Ін-т мовознавства імені О.О. Потебні; редкол.: І.К. Білодід (голова) та ін. Київ : Наук. думка, 1970-1980. Т. 2: Г-Ж. Ред. тому: П.П. Доценко, Л.А. Юрчук. 1971. С. 399.

${ }^{2}$ Словник української мови : в 11 т. / АН УРСР, Ін-т мовознавства імені О.О. Потебні; редкол.: І.К. Білодід (голова) та ін. Київ : Наук. думка, 1970-1980. Т. 2 : Г-Ж. Ред. тому: П.П. Доценко, Л.А. Юрчук. 1971. С. 492.
} 
суду, знищити речі, що мають значення для кримінального провадження тощо); по-друге, чи $\epsilon$ він корисним як для органів кримінального судочинства, так і для самого неповнолітнього. Для встановлення ефективності застосування запобіжного заходу щодо неповнолітнього слід виходити із того, чи призведе це до потрібних результатів та наслідків.

\section{1. Особливості застосування неізоляційних запобіжних заходів щодо неповнолітнього підозрюваного, обвинуваченого}

Дослідження статистичних даних свідчить про той факт, що обрання запобіжних заходів щодо неповнолітнього має свою специфіку. Для цього наведемо дані про кількість поданих до суду клопотань про застосування запобіжних заходів щодо неповнолітніх протягом 2013-2019 рр. ${ }^{3}$ (табл. 1).

Таблиця 1

Дані про кількість поданих до суду клопотань про застосування запобіжних заходів щодо неповнолітніх протягом 2013-2019 pp.

\begin{tabular}{|c|c|c|c|c|c|c|c|}
\hline $\begin{array}{c}\text { Подано до суду } \\
\text { клопотань про } \\
\text { застосування } \\
\text { запобіжних заходів } \\
\text { щодо } \\
\text { неповнолітнього }\end{array}$ & 2013 p. & 2014 p. & $2015 p$. & $2016 \mathrm{p}$. & 2017 p. & $2018 \mathrm{p}$. & 2019 p. \\
\hline Всього, $з$ них: & 584 & 1369 & 1231 & 920 & 987 & 900 & 784 \\
\hline $\begin{array}{l}\text { Особисте } \\
\text { зобов'язання }\end{array}$ & & $\begin{array}{c}612 \\
(44,7 \%)\end{array}$ & $\begin{array}{c}469 \\
(38 \%)\end{array}$ & $\begin{array}{c}297 \\
(32,3 \%)\end{array}$ & $\begin{array}{c}274 \\
(27,7 \%)\end{array}$ & $\begin{array}{c}164 \\
(18,2 \%)\end{array}$ & $\begin{array}{c}153 \\
(19,5 \%)\end{array}$ \\
\hline Застава & $\begin{array}{c}2 \\
(0,3 \%)\end{array}$ & 0 & 0 & $\begin{array}{c}1 \\
(0,1 \%)\end{array}$ & 0 & 0 & 0 \\
\hline Домашній арешт & $\begin{array}{c}275 \\
(47,1 \%) \\
\end{array}$ & $\begin{array}{c}375 \\
(27,4 \%) \\
\end{array}$ & $\begin{array}{c}377 \\
(30,6 \%) \\
\end{array}$ & $\begin{array}{c}303 \\
(32,9 \%) \\
\end{array}$ & $\begin{array}{c}360 \\
(36,4 \%) \\
\end{array}$ & $\begin{array}{c}398 \\
(36,4 \%) \\
\end{array}$ & $\begin{array}{c}339 \\
(43,2 \%) \\
\end{array}$ \\
\hline $\begin{array}{l}\text { Тримання під } \\
\text { вартою }\end{array}$ & $\begin{array}{c}307 \\
(52,6 \%)\end{array}$ & $\begin{array}{c}325 \\
(27,3 \%)\end{array}$ & $\begin{array}{c}358 \\
(29,1 \%)\end{array}$ & $\begin{array}{c}299 \\
(32,5 \%)\end{array}$ & $\begin{array}{c}349 \\
(35,3 \%)\end{array}$ & $\begin{array}{c}333 \\
(37 \%)\end{array}$ & $\begin{array}{c}292 \\
(37,2 \%)\end{array}$ \\
\hline
\end{tabular}

Перш за все слід з'ясувати питання щодо доцільності застосування щодо неповнолітнього підозрюваного, обвинуваченого такого запобіжного заходу, як особисте зобов'язання. Наведені вище статистичні дані свідчать про тенденцію зменшення кількості обрання таких заходів, оскільки у 2013 р. прокурором було подано 612 клопотань про обрання запобіжного заходу, що становило $44,7 \%$ від загальної кількості запобіжних заходів до неповнолітніх, а у 2019 р. - 153 клопотання (19,5\%). Тобто кількість вибраних запобіжних заходів у вигляді особистого зобов'язання зменшилась майже в 2,3 раза (рис. 1 ).

\footnotetext{
${ }^{3}$ Звіт про роботу прокурора за 2013-2019 pp. URL: https://old.gp.gov.ua/ua/statinfo.html.
} 


\section{Обрання запобіжного заходу \\ у вигляді особистого зобов'язання \\ щодо неповнолітнього підозрюваного, обвинуваченого \\ протягом 2014-2019 pp.}

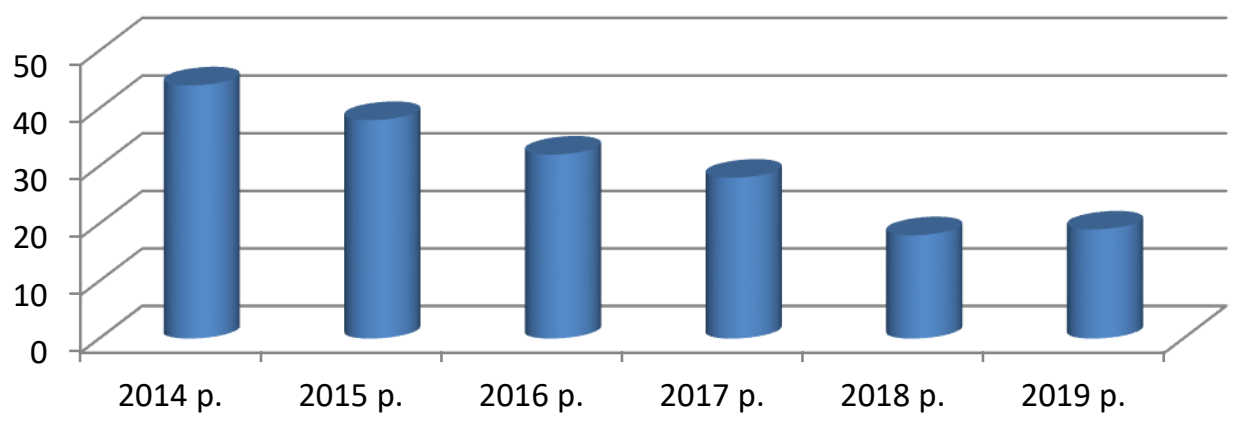

Рис. 1. Дані про обрання запобіжного заходу у вигляді особистого зобов'язання щодо неповнолітнього підозрюваного, обвинуваченого протягом 2014-2019 рр. (у \%)

Слід звернути увагу на той факт, що особисте зобов'язання за своєю природою $є$ заходом, що здійснює психічний вплив на особу, передбачає лише загрозу застосування більш суворого запобіжного заходу. Здебільшого для забезпечення належної поведінки неповнолітнього такого впливу не досить. Така позиція обгрунтовується тим, що особистість підлітка характеризується надмірною запальністю, неадекватною оцінкою певної ситуації, схильністю копіювати дії дорослих та оточуючих. А отже, здебільшого неповнолітньому для виконання своїх обов'язків потрібен вплив авторитетної для нього людини. 3 цього приводу М.I. Капінусом було проведено дослідження, згідно з яким встановлено, що дорослі порушують умови підписки про невиїзд (яка $є$ схожою з особистим зобов'язанням) у 2,9\% випадків обрання цього запобіжного заходу, а неповнолітні - в 10,5\% ${ }^{4}$. Такі дані слід брати до уваги для врахування ризиків негативної поведінки підлітка під час здійснення кримінального провадження.

Отже, на наше переконання, особисте зобов'язання для неповнолітнього $\epsilon$ малоефективним заходом, оскільки він не усвідомлюється підлітком повною мірою, не забезпечує належного контролю за його поведінкою та не здійснює стримуючого впливу. Вважаємо, що загальна для України тенденція зменшення кількості вибраних запобіжних заходів щодо

\footnotetext{
4 Капинус Н.И. Процессуальные гарантии прав личности при применении мер пресечения в уголовном процессе : монография. Москва : Буковед, 2007. 416 с.
} 
неповнолітнього у вигляді особистого зобов'язання відображає нашу позицію щодо малоефективності такого заходу.

Для забезпечення належної поведінки неповнолітнього підозрюваного, обвинуваченого необхідним є використання додаткових заходів примусу, зокрема 3 боку осіб, які користуються авторитетом і $\epsilon$ позитивним прикладом для нього. Серед запобіжних заходів, що використовують моральний вплив на правопорушника, є особиста порука. Такий захід у разі його застосування до неповнолітнього $є$ аналогічним переданню під нагляд. Відмінність у цих заходах полягає в тому, що законодавцем у положеннях ст. 493 КПК України, якими регламентовано порядок передання неповнолітнього під нагляд, заздалегідь визначено коло осіб, які можуть впливати на неповнолітню особу. Для неповнолітніх це $\epsilon$ батьки, опікуни, піклувальники, адміністрація дитячої установи.

Разом із тим до неповнолітнього підозрюваного, обвинуваченого може бути застосована й особиста порука (відомості щодо кількості випадків застосування особистої поруки до неповнолітніх у статистичних даних ГПУ відсутні). Й у такому разі поручителями, тобто особами, які здійснюватимуть вплив на неповнолітнього, можуть бути не лише батьки, а й інші особи, які викликають довіру у слідчого судді, суду. Віддання пріоритету вибранню особистої поруки, ніж переданню під нагляд, є доцільним у випадках, наприклад, коли батьки ведуть антисоціальний образ життя і не здійснюють позитивного впливу на неповнолітнього. У такому разі одним поручителем неповнолітнього може стати дорослий родич, а другим - особа, яка спілкується з підлітком за місцем роботи/навчання. А отже, під час вибору поручителів 3 метою найбільшого охоплення різних сфер діяльності останнього має бути враховане соціальне життя неповнолітнього. Й у разі негативного, антисоціального способу життя батьків підлітка та ймовірності позитивного впливу інших осіб - поручителів на неповнолітнього більш доцільним буде обрання саме особистої поруки, а не передання під нагляд.

Вирішуючи питання про застосування застави як запобіжного заходу, слід брати до уваги, що у неповнолітнього, як правило, немає власних коштів, які він би міг внести як матеріальне забезпечення належної поведінки. Відповідно, заставодавцем виступатимуть зазвичай батьки або інші близькі родичі. Отже, якщо заставодавцем виступатиме не сам неповнолітній, а інші особи, то майновий вплив на підлітка не матиме такого стимулюючого ефекту, як для дорослого, оскільки через вік він не може повною мірою усвідомлювати матеріального стимулу. 3 цього приводу О.В. Сівак слушно вказує, що неповнолітній може розуміти застосування щодо нього застави як факт того, що від будь-якого покарання можна «відкупитися», внісши лише вказану суму і надалі займатися злочинною 
діяльністю. Тобто свідомого розуміння застосованого щодо нього запобіжного заходу у вигляді застави останній не отримає, виховного впливу на правосвідомість неповнолітнього правопорушника здійснено не буде 5 .

Проаналізувавши статистику застосування застави як запобіжного заходу щодо неповнолітніх, можемо впевнено зробити висновок, що практичними працівниками цей захід майже не застосовується (табл. 1). Так, у 2014, 2015, 2017-2019 рр. застава щодо неповнолітніх взагалі не застосовувалась, а у 2013 р. та у 2016 р. такий захід вибирався в поодиноких випадках.

Окремо слід звернути увагу на той факт, що застава може бути застосована як альтернатива триманню під вартою, оскільки положення ч. 3 ст. 183 КПК України стосуються всіх категорій підозрюваних, обвинувачених, у тому числі неповнолітніх. Безумовно, застава $є$ менш суворим запобіжним заходом, ніж тримання під вартою. А отже, за наявності відповідних підстав, у тому числі з урахуванням майнового стану батьків чи самого неповнолітнього, у кожному конкретному випадку повинно бути вирішено питання про визначення певного розміру застави. Але, як показав аналіз статистичних даних ГПУ, таку альтернативу на практиці використовують доволі рідко. Зокрема, у 2013 р. на стадії досудового розслідування у зв'язку із внесенням застави звільнено лише 2 неповнолітні особи, у 2014 р. відповідно - 2, у 2015 p. -4 , y 2016 p. -1 , y 2017 p. -0 , y 2018 p. -2 , y 2019 p. $-5^{6}$.

Отже, вирішуючи питання про вибір оптимального виду запобіжного заходу щодо неповнолітнього, ми вважаємо за недоцільне та неефективне обрання застави у випадку, коли внесення коштів здійснюють близькі родичі або члени сім’ї неповнолітнього. Імовірно, що для підлітка така обставина не матиме стимулу належної поведінки. Інша ситуація, коли заставу внесено самим неповнолітнім підозрюваним, обвинуваченим. У такому разі внесення самостійно зароблених коштів явно матиме матеріальний стимул належної поведінки. Втім у реаліях сьогодення, коли неповнолітні, які вчиняють кримінальні правопорушення, здебільшого живуть у неблагополучних сім'ях, і відповідно, не працюють, внесення ними застави є скоріш винятком.

До неізоляційних запобіжних заходів, що можуть бути застосовані до неповнолітніх, слід віднести передання під нагляд. Залежно від того, кому може передаватися неповнолітній під нагляд, такий вид запобіжного заходу має два підвиди: 1) передача неповнолітнього підозрюваного, обвинуваченого під нагляд батьків, опікунів, піклувальників; 2) передача

\footnotetext{
${ }^{5}$ Сівак О.В. Критерії доцільності й ефективності застосування застави як запобіжного заходу в кримінальних провадженнях щодо неповнолітніх. Вісник Запорізького наиіонального університету. 2015. № 1 (II). C. 226.

${ }^{6}$ Звіт про роботу прокурора за 2013-2019 pp. URL: https://old.gp.gov.ua/ua/statinfo.html.
} 
неповнолітнього підозрюваного, обвинуваченого під нагляд адміністрації дитячої установи, в якій виховується неповнолітній. Згідно зі статистичними даними, у 2018 р. запобіжний захід у вигляді передання під нагляд було застосовано судом лише 1 раз, а у 2019 р. -7 разів $^{7}$. Тобто помічаємо, що такий спеціальний запобіжний захід на практиці майже не застосовується.

Для порівняння зазначимо, що пріоритет застосування запобіжного заходу у вигляді передання під нагляд до неповнолітнього прямо визначено на законодавчому рівні деяких країн (ст. 432 КПК Республіки Білорусь, ст. 477 КПК Республіки Молдова, ст. 491 Республіки Казахстан, ст. 423 КПК Російської Федерації). В українському кримінальному процесуальному законодавстві немає прямої вказівки віддавати пріоритет такому заходу, проте $\epsilon$ вимога до слідчого судді, суду встановлювати обставини, які свідчать про недостатність застосування більш м'яких запобіжних заходів (п. 3 ч. 1 ст. 194 КПК України). Отже, як бачимо, альтернативу у вигляді передання під нагляд на практиці майже не використовують.

Тому слідчим і судовим органам усе ж таки слід пам'ятати, що передання під нагляд $\epsilon$ одним із найефективніших заходів. Слід враховувати той факт, що у разі його обрання неповнолітній перебуває під наглядом батьків. У межах сім'ї батьки мають не тільки право, а й зобов'язані забезпечити догляд і нагляд за своїми дітьми. У такому разі слід врахувати вимоги Пекінських правил, що жоден неповнолітній не може бути вилучений з-під нагляду батьків частково або повністю, якщо це не виправдано обставинами іiї або його справи (правило 18.2) ${ }^{8}$.

Передання під нагляд означає не лише встановлення нагляду за неповнолітнім, а й проведення батьками чи іншими особами роз'яснювальної роботи 3 ним, переконання у законослухняній поведінці, необхідності сприяння органам розслідування у встановленні обставин кримінального правопорушення. Серед переваг такого заходу окремі науковці також відзначають те, що передання під нагляд, з одного боку, дає неповнолітньому шанс усвідомити свою поведінку й оцінити рівень довіри слідчого та особи, яка погодилась взяти його на поруки, а з іншого у слідчого $є$ можливість проконтролювати неповнолітнього, визначити ступінь вираженості його антисуспільної поведінки, проаналізувати можливості його виправлення 9 . Слід враховувати, що в окремих випадках

\footnotetext{
7 Звіт суддів першої інстанції про розгляд матеріалів кримінального провадження за 2018-2019 рр. Форма 1-к. Розділ 3. URL: https://lg.arbitr.gov.ua/inshe/sudova_statystyka/.

Мінімальні стандартні правила Організації Об'єднаних Націй, що стосуються відправлення правосуддя щодо неповнолітніх («Пекінські правила») Міжнародний документ від 29.11.1985. URL: https://zakon.rada.gov.ua/laws/show/995_211.

9 Пастушенко С.В. Застосування запобіжних заходів до неповнолітнього підозрюваного, обвинуваченого. Актуальні питання кримінального процесу, криміналістики та судової експертизи :
} 
обрання такого заходу буде неефективним та недоцільним. Йдеться, зокрема, про випадки, коли неповнолітня особа офіційно уклала шлюб та проживає разом із дружиною/чоловіком. Зрозуміло, що коли така особа проживає окремо від батьків застосування запобіжного заходу у вигляді передання під нагляд $є$ недоцільним.

\section{2. Особливості застосування ізоляційних запобіжних заходів щодо неповнолітнього підозрюваного, обвинуваченого}

Ізоляційними запобіжними заходами, що можуть бути застосовані до неповнолітнього підозрюваного, обвинуваченого, $\epsilon$ домашній арешт, тримання під вартою, а також затримання як тимчасовий запобіжний захід. Безсумнівно, першою і головною перевагою обрання домашнього арешту до неповнолітніх $\epsilon$ те, що він $\epsilon$ дієвою альтернативою триманню під вартою. Про це наочно свідчать наведені нами статистичні дані. Як бачимо, домашній арешт протягом 2013-2019 рр. застосовувався до неповнолітніх у $27 \%-47 \%$ випадків (рис. 2 ).

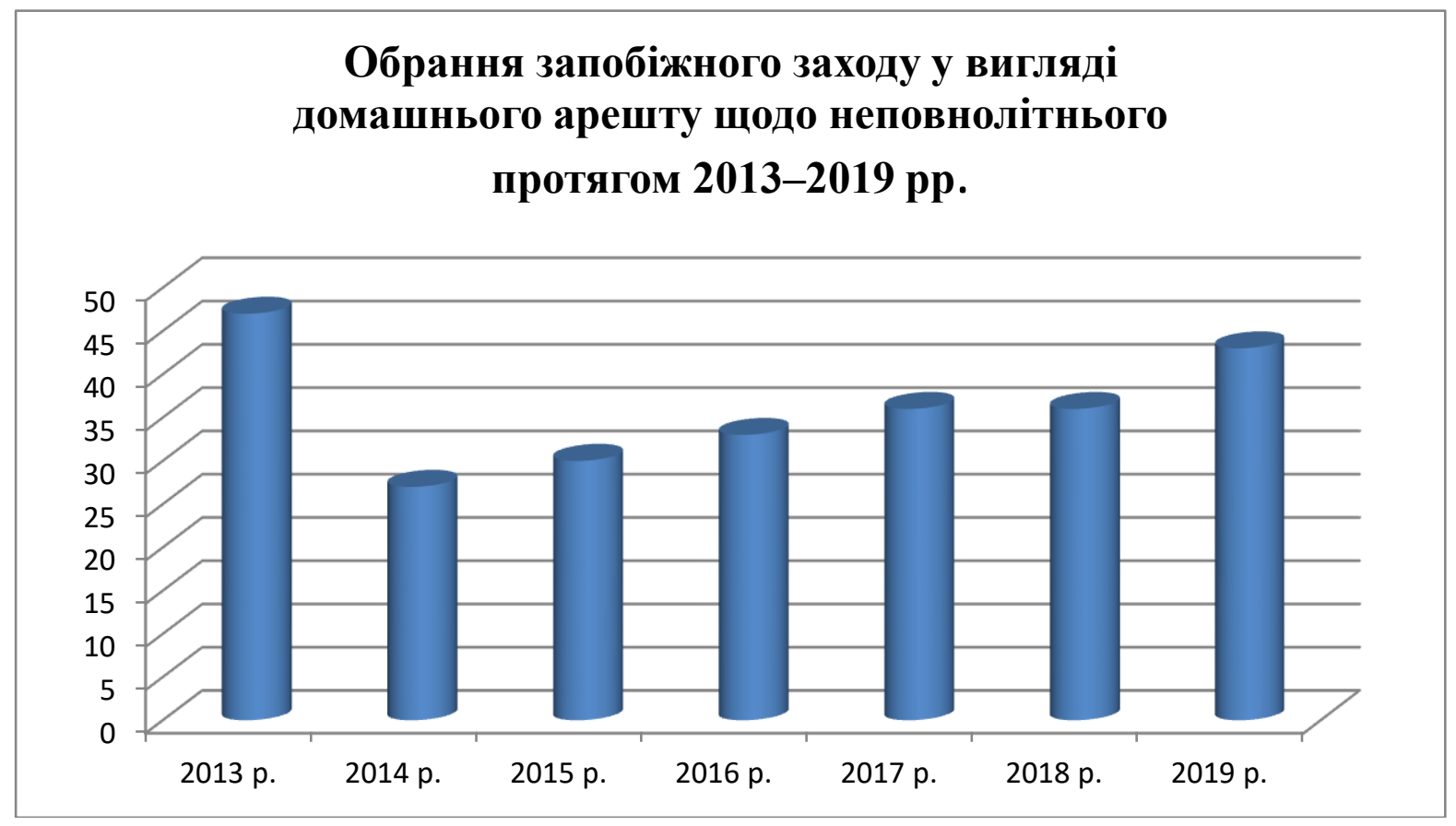

Рис. 2. Дані про обрання запобіжного заходу у вигляді домашнього арешту щодо неповнолітнього підозрюваного, обвинуваченого протягом 2013-2019 pp. (у \%)

матеріали міжвідом. наук.-практ. конф. (Київ, 24 листоп. 2017 р.): у 2 ч. Ч. 1. / редкол.: В.В. Чернєй, С.С. Чернявський, Л.Д. Удалова та ін. Київ : Нац. акад. внутр. справ, 2017. С. 128. 
Про перевагу застосування домашнього арешту до неповнолітнього вказують і більшість науковців ${ }^{10}$. Зокрема, О.П. Кучинська ще до прийняття чинного КПК України зазначала про те, що слушним було би застосування домашнього арешту до неповнолітніх осіб, що обвинувачуються у скоєнні злочинів, адже їхнє перебування в ізоляторі тимчасового тримання чи у слідчому ізоляторі не тільки не справляє виховного впливу, а навпаки, шкодить дитячій психіці. А це може призвести і призводить до того, що неповнолітні, один раз випадково «спіткнувшись», стають на шлях злочинної діяльності ${ }^{11}$. Погоджуючись із такою позицією, підкреслимо, що, перебуваючи під домашнім арештом, неповнолітній не відчуває на собі того жорсткого тиску, як під час тримання під вартою в слідчому ізоляторі. Перебуваючи у специфічних умовах ізолятора, неповнолітній не лише піддається безперервному стресу, а й потрапляє під вплив оточуючого його середовища - «кримінального елемента». Потрапляючи до місць позбавлення волі, несформована особистість підлітка піддається «імплантації» норм злочинного світу. Отже, вказане свідчить про доцільність застосування домашнього арешту як альтернативи триманню під вартою щодо неповнолітніх.

Ще один аспект, на який слід звернути увагу, - це здійснення контролю за виконанням домашнього арешту. Контроль за виконанням ухвали про обрання такого запобіжного заходу до неповнолітнього або продовження строку його дії слідчі судді, як правило, покладають на начальника органу Національної поліції (далі - НП) ${ }^{12}$, який повинен визначити структурний підрозділ, що буде здійснювати контроль за виконанням неповнолітнім підозрюваним, обвинуваченим обов'язків, покладених у зв'язку із застосуванням домашнього арешту. За проведеним дослідженням у такому разі найчастіше контроль покладається на дільничних офіцерів поліції. Але, на наше переконання, нагляд повинні здійснювати не вони, а працівники підрозділу ювенальної превенції органів Національної поліції, на яких серед іншого покладено завдання профілактичної діяльності, спрямованої на запобігання вчиненню дітьми правопорушень тощо. Слід звернути увагу на той факт, що ані в Інструкції про порядок виконання органами НП ухвал слідчого судді, суду про обрання запобіжного заходу у

10 Вільгушинський М.Й., Ліхолєтова Ю.А. До питання застосування домашнього арешту як запобіжного заходу відповідно до Кримінального процесуального кодексу України. Адвокат. 2012. № 11. C. 10.

11 Кучинська О.П. Домашній арешт як запобіжний захід у кримінально-процесуальному законодавстві. Адвокат. 2010. № 7 (118). С. 18.

12 Ухвала судді Острозького районного суду Рівненської області від 18.07.2018, справа № 567/1397/17. URL: http://www.reyestr.court.gov.ua/Review/75353310; Ухвала судді Мелітопольського міськрайонного суду Запорізької області від 26.04.2017, справа № 320/1562/17-к. URL: http://www.reyestr.court.gov.ua/ Review/67335930. 
вигляді домашнього арешту (Наказ МВС України від 13.07.2016 p. № $\left.654^{13}\right)$, ані в Інструкції $з$ організації роботи підрозділів ювенальної превенції Національної поліції України (наказ МВС України від 19.12.2017 p. № $1044^{14}$ ) не визначено особливостей здійснення контролю за виконанням домашнього арешту неповнолітнім. А отже, з огляду на той факт, що працівники саме цього підрозділу повинні здійснювати контроль за неповнолітніми правопорушниками, вважаємо, що варто внести відповідні зміни у вказані нормативно-правові акти.

Ще однією перевагою обрання домашнього арешту щодо неповнолітнього $\epsilon$ те, що контроль за його виконанням здійснюють не лише органи НП, а й батьки, опікуни, особи. Хоча обов'язок батьків наглядати за підлітком-правопорушником нормативно не визначено, фактично вони також контролюють його, чим сприяють досягненню мети застосування запобіжного заходу. Отже, з огляду на наведені переваги застосування домашнього арешту щодо неповнолітніх підозрюваних, обвинувачених, вважаємо, що він $є$ одним із найефективніших запобіжних заходів, який доцільно вибирати до такої категорії правопорушників.

Разом із тим не можна виключати ситуацію, коли агресивна поведінка неповнолітнього, який вчинив тяжкий чи особливо тяжкий злочин, свідчить про те, що лише шляхом повної ізоляції від суспільства можна виключити можливість його неналежної поведінки та забезпечити участь під час досудового розслідування та/або суду. Тому законодавець допускає можливість обрання щодо неповнолітнього запобіжного заходу у вигляді тримання під вартою (ч. 2 ст. 492 КПК України).

На відміну від раніше діючого правила, що містилось у ст. 434 КПК України 1960 р. про винятковість взяття під варту неповнолітнього, нині чинні законодавчі положення таких вимог не встановлюють. У ч. 2 ст. 492 чинного КПК України йдеться лише про дві умови обрання тримання під вартою щодо неповнолітнього: 1) особа підозрюється або обвинувачується у вчиненні тяжкого чи особливо тяжкого злочину; 2) застосування іншого запобіжного заходу не забезпечить запобігання ризикам, зазначеним у ст. 177 КПК України. Слід звернути увагу, що у п. «b» ст. 37 Конвенції $\mathrm{OOH}$ «Про права дитини» щодо арешту, затримання чи тюремного ув'язнення дитини вказано, що вони використовуються лише як крайній

\footnotetext{
13 Про затвердження Інструкції про порядок виконання органами Національної поліції ухвал слідчого судді, суду про обрання запобіжного заходу у вигляді домашнього арешту та про зміну раніше обраного запобіжного заходу на запобіжний захід у вигляді домашнього арешту : Наказ МВС України від 13.07.2016 p. № 654. URL: http://zakon.rada.gov.ua/laws/show/z1087-16.

${ }^{14}$ Про затвердження Інструкції з організації роботи підрозділів ювенальної превенції Національної поліції України : Наказ МВС України від 19.12.2017 p. № 1044. URL: https://zakon.rada.gov.ua/laws/ show/z0686-18.
} 
захід і протягом якомога більш короткого відповідного періоду часу ${ }^{15}$. Аналогічні вимоги закріплено й у Пекінських правилах (правило 13 «Тримання під вартою до суду»). На ці положення звернуто увагу й у п. 6 листа ВССУ від 18.07.2013 р. № 223-1134/0/4-13, у якому вказано, що тримання під вартою має застосовуватись до неповнолітнього лише у виняткових випадках як крайня міра, 3 визначенням якомога коротших термінів такого тримання ${ }^{16}$. Разом із тим винятковість тримання під вартою передбачена у загальній нормі (ст. 183 КПК України). Відповідно, така вимога поширюється і на спеціальну норму (ст. 432 КПК України). Отже, правило винятковості найсуворішого запобіжного заходу поширюється як на випадки обрання тримання під вартою щодо дорослих підозрюваних, обвинувачених, так i неповнолітніх. А отже, вести мову про те, що тримання під вартою не $\epsilon$ винятковим запобіжним заходом для неповнолітніх, буде не зовсім коректно.

Вирішуючи питання про застосування запобіжного заходу щодо неповнолітнього підозрюваного, обвинуваченого, слідчому судді, суду необхідно встановити, чи доводять надані докази обставини, що свідчать про недостатність застосування більш м'яких запобіжних заходів (п. 3 ч. 1 ст. 194 КПК України). А отже, обов'язково повинно бути вирішено питання про можливість обрання неповнолітньому альтернативного триманню під вартою заходу, зокрема, домашнього арешту, передання під нагляд чи іншого, більш м'якого, заходу. Важливим для доведення такої позиції є рішення ЄСПЛ у справі «Свершов проти України», в якому Суд констатував порушення вимог статті 5 Конвенції про захист прав людини та основоположних свобод стосовно неповнолітнього. У пункті 63 цього рішення в обгрунтування порушення статті 5 Конвенції ССПЛ зазначив, що національні суди під час розгляду питання щодо продовження тримання під вартою неповнолітнього жодного разу не розглядали можливості обрання альтернативного запобіжного заходу замість тримання під вартою i, посилаючись головним чином на тяжкість злочинів, продовжували тримати заявника під вартою на підставах, які не можна вважати «відповідними і достатніми» ("Svershov v. Ukraine”, заява № 35231/02, § 63, від 27 листопада 2008 року) ${ }^{17}$.

Як показав аналіз статистичних даних, протягом 2013-2019 рр. найсуворіший захід застосовувався до неповнолітніх у 30-53\% випадків!

\footnotetext{
15 Конвенція про права дитини: Міжнародний документ від 20.11.1989 p. URL: https://zakon.rada.gov.ua/laws/main/995_021.

${ }^{16}$ Про деякі питання здійснення кримінального провадження щодо неповнолітніх : Лист ВССУ від 18.07.2013 р. № 223-1134/0/4-13. URL: https://zakon.rada.gov.ua/laws/show/v1134740-13.

17 Рішення Свропейського Суду 3 прав людини у справі «Свершов проти України» (Svershov v. Ukraine), заява № 35231/02, від 27 листопада 2008 року. URL: https://zakon.rada.gov.ua/laws/main/974_428.
} 
Тобто третину від усіх запобіжних заходів (а у 2013 р. - половина) становить саме тримання під вартою (рис. 3).

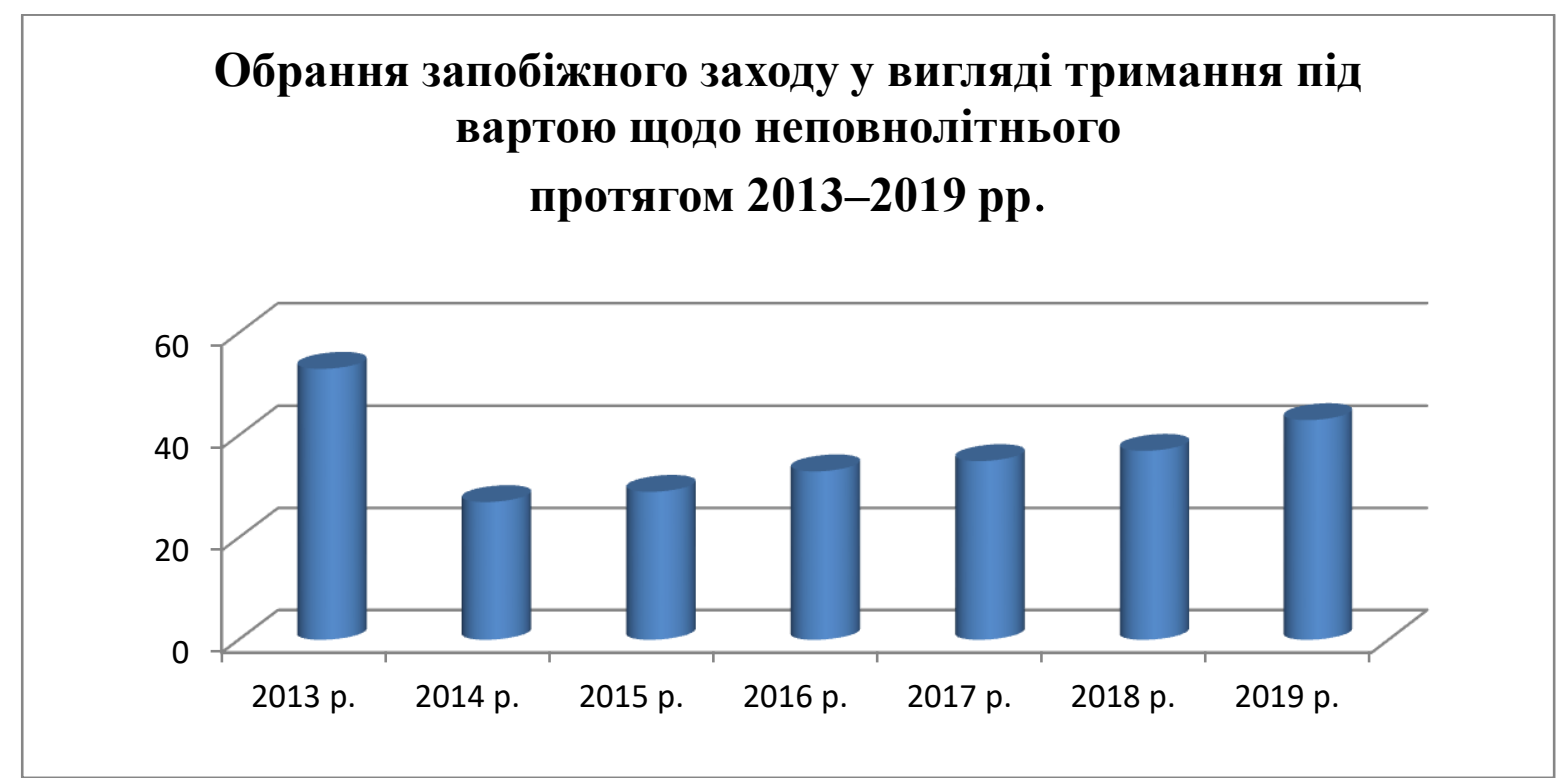

\section{Рис. 3. Дані про обрання запобіжного заходу у вигляді тримання під вартою щодо неповнолітнього підозрюваного, обвинуваченого протягом 2014-2019 pр. (у \%)}

Надмірне застосування тримання під вартою щодо неповнолітніх викликано насамперед прагненням слідчого, прокурора, суду попередити ухилення підлітка від органів досудового розслідування та суду. Тому навряд чи буде правильним вважати, що це єдиний захід, що може попередити таке ухилення. Комітет міністрів Ради Європи вже неодноразово рекомендував використовувати «альтернативні заходи» триманню під вартою й особливо така рекомендація стосується неповнолітніх. Поміщення із родичами, прийомними батьками та інші форми підтримуючого влаштування визначаються як альтернативи триманню під вартою для неповнолітніх підозрюваних у Рекомендації $\operatorname{Rec}(2003) 20$ Комітету Міністрів державам-учасницям щодо нових підходів у вирішенні проблеми злочинності серед неповнолітніх та ролі ювенальної юстиції (стаття 17). Потреба у впровадженні «достатньої кількості досить різнорідних» заходів визнана у Додатку 2 до Рекомендації Rec (2000) 22 Комітету Міністрів державам-учасницям щодо поліпшення впровадження Європейських правил щодо санкцій та заходів на місцевому рівні ${ }^{18}$.

${ }^{18}$ Рекомендація Rec (2006) 13 Комітету Міністрів державам-учасницям щодо застосування тримання під вартою умов, у яких воно відбувається, і запровадження гарантій від зловживань з Пояснювальною запискою. Прийнята Комітетом Міністрів 27.09.2006 р. на 974-й зустрічі заступників міністрів. URL: http://khpg.org/index.php?id=1166617725. 
Окремому вивченню підлягає питання щодо доцільності знаходження неповнолітнього, який вступив у конфлікт із законом, у спеціальній установі. У Пекінських правилах встановлена вимога тримання під вартою неповнолітніх окремо від дорослих, а також у спеціальній установі або в спеціальному відділенні установи, де утримуються також i дорослі (правило 13.4). Положення про роздільне тримання у місцях попереднього ув'язнення неповнолітніх від дорослих передбачено й у ст. 8 Закону України «Про попереднє ув'язнення».

Натепер в Україні неповнолітні особи, щодо яких вибрано запобіжний захід у вигляді тримання під вартою, перебувають у тих же СІЗО, що і дорослі, хоча й у спеціальному блоці. Втім Європейський комітет з питань запобігання катуванням чи нелюдському або такому, що принижує гідність, поводженню чи покаранню (далі - СКЗК) уже давно виступає за те, щоб усі затримані неповнолітні, підозрювані або обвинувачені у скоєнні злочину, утримувалися в центрах затримання, спеціально призначених для осіб цього віку, в яких середовище не нагадує в'язницю, а режим враховує їхні потреби, та в яких працюють особи, навчені поводженню $з$ неповнолітніми. На жаль, у багатьох державах-членах Ради Європи, у тому числі й в Україні, стан справ є далеким від цього. Вважаємо, що національному законодавцю слід «прислухатись» до рекомендацій ЄКЗК, який у п. 102 24-ої Загальної доповіді у 2015 р. наголосив, що неповнолітні (незалежно від того, перебувають вони під вартою або відбувають покарання) повинні, як правило, утримуватися не в установах для дорослих, а натомість у місцях, спеціально призначених для їхньої вікової групи ${ }^{19}$.

Сучасні СІЗО мають погані матеріальні умови. У зв'язку з відсутністю навченого персоналу щодо поводження 3 неповнолітніми їх підтримка та контроль залишаються неадекватними. Це означає, що неповнолітні не займаються цілеспрямованою діяльністю та не навчаються життєвих навичок, які корисні для реінтеграції у суспільство після звільнення з-під варти. Зауважимо, що у науковій літературі пропонувалось запровадити новий запобіжний захід - «поміщення неповнолітнього підозрюваного чи обвинуваченого до спеціалізованої дитячої установи закритого типу» ${ }^{20}$. Ми вважаємо, що змінювати потрібно не назву запобіжного заходу, а умови його виконання. Отже, ми переконані у необхідності створення спеціально призначених установ для тримання під вартою неповнолітніх. У таких установах повинен працювати персонал, який спеціально навчений

\footnotetext{
${ }^{19}$ Неповнолітні, позбавлені волі відповідно до кримінального законодавства: Витяг з 24-ої Загальної доповіді Свропейського комітету з питань запобігання катуванням чи нелюдському або такому, що принижує гідність, поводженню чи покаранню. CPT/Inf(2015)1-part. URL: https://rm.coe.int/16806ccb95.

${ }^{20}$ Сівак О.В. Запобіжні заходи у кримінальному провадженні щодо неповнолітніх : дис. ... канд. юрид. наук : 12.00.09. Київ, 2016. С. 192.
} 
поводженню 3 неповнолітніми, забезпечено умови для навчання неповнолітніх. Іноді судовий розгляд у кримінальному провадженні щодо неповнолітніх може тривати більше трьох років. А тому перебування підлітка в СІЗО тривалий час без будь-яких навчальних заходів не лише свідчить про відсутність виховного процесу, а й нівелює у майбутньому його ресоціалізацію.

Вважаємо, що для України створення спеціально призначених установ для тримання під вартою неповнолітніх повинно стати стратегічною метою. Зрозуміло, що це вимагає здійснення низки організаційних дій, у тому числі й побудову установ, внесення змін до законодавчих актів тощо. Втім, як уже було вказано, сучасний стан тримання неповнолітніх під вартою, тобто тоді, коли особа ще не визнана судом винуватою, не відповідає загальновизнаним правилам поводження з неповнолітніми правопорушниками.

\section{ВИСНОВКИ}

Поставивши перед собою мету - дослідити питання доцільності та ефективності застосування запобіжних заходів щодо неповнолітніх підозрюваних, обвинувачених, зауважимо найефективнішим його видом стосовно такої категорії осіб є передання під нагляд, який з огляду на дослідження на практиці, на жаль, застосовується в одиничних випадках. Отже, правозастосувачу й зокрема слідчому, прокурору, судді слід враховувати таке. По-перше, міжнародними правовими актами, які $\epsilon$ частиною національного законодавства (зокрема, Пекінськими правилами й Конвенцією про права дитини) встановлена вимога застосовувати ті заходи впливу щодо неповнолітніх, які по можливості не відлучають неповнолітню особу від батьків. У кримінальному процесуальному законодавстві України таким заходом, зокрема, $є$ передання під нагляд. Подруге, за своєю правовою природою передання під нагляд, з огляду на постійний нагляд та виховний вплив батьків чи інших осіб, адміністрації дитячої установи, $\epsilon$ найбільш ефективним та доцільним запобіжним заходом, що може вибратися стосовно неповнолітнього.

Особисте зобов'язання для неповнолітнього є малоефективним заходом, оскільки не усвідомлюється ним повною мірою, не забезпечує належного контролю за його поведінкою та не здійснює стримуючого впливу. Недоцільним та неефективним є обрання застави, коли внесення коштів здійснюють близькі родичі або члени сім'ї неповнолітнього. Домашній арешт як альтернатива триманню під вартою має певні переваги, а тому його обрання щодо неповнолітніх $є$ доцільним та ефективним.

Обрання тримання під вартою стане тоді обгрунтованим, коли будуть дотримані такі умови і правила його застосування: 1) тримання під вартою 
$\epsilon$ винятковим запобіжним заходом для неповнолітнього; і це передбачає, що він є єдиним можливим заходом у певній ситуації і застосування іншого, більш м'якого запобіжного заходу не забезпечить запобігання ризикам; 2) тримання під вартою застосовується у виключних випадках, коли неповнолітня особа підозрюється або обвинувачується у вчиненні тяжкого чи особливо тяжкого злочину; 3) перед обранням тримання під вартою або продовженням строку його дії слід визначити можливість про застосування альтернативного заходу, зокрема, домашнього арешту або передання під нагляд; 4) неповнолітні повинні триматися під вартою окремо від дорослих у спеціальній установі або в спеціальному відділенні установи, де утримуються також і дорослі. 3 урахуванням нагальної потреби у зміні підходу щодо поводження із неповнолітніми підозрюваними, обвинуваченими вважаємо необхідним створення в Україні спеціально призначених установ для тримання їх під вартою.

\section{АНОТАЦІЯ}

Висвітлено питання доцільності та ефективності застосування запобіжних заходів щодо неповнолітніх підозрюваних, обвинувачених. Наведено статистичні дані щодо їх обрання. Доведено, що найефективнішим його видом стосовно такої категорії осіб є передання під нагляд, який з огляду на дослідження на практиці застосовується в одиничних випадках. Акцентовано увагу, що особисте зобов'язання для неповнолітнього $\epsilon$ малоефективним заходом. Домашній арешт як альтернатива триманню під вартою має певні переваги, а тому його обрання щодо неповнолітніх $\epsilon$ доцільним та ефективним. Застосування застави, навпаки, є недоцільним, коли внесення коштів здійснюють близькі родичі або члени сім’і неповнолітнього. З'ясовано, що протягом 2013-2019 pp. тримання під вартою до неповнолітніх застосовувалось у $30-53 \%$ випадків. Сформульовано умови і правила його застосування щодо цієї категорії осіб. Обгрунтована позиція про необхідність створення в Україні спеціально призначених установ для тримання під вартою неповнолітніх осіб.

\section{ЛIТЕРАТУРА}

1. Вільгушинський М.Й., Ліхолєтова Ю.А. До питання застосування домашнього арешту як запобіжного заходу відповідно до Кримінального процесуального кодексу України. Адвокат. 2012. № 11. С. 9-13.

2. Звіт суддів першої інстанції про розгляд матеріалів кримінального провадження за 2018-2019 pp. Форма 1-к. Розділ 3. URL: https://lg.arbitr.gov.ua/inshe/sudova_statystyka/.

3. Звіт про роботу прокурора за 2013-2019 pp. URL: https:// old.gp.gov.ua/ua/statinfo.html. 
4. Капинус Н.И. Процессуальные гарантии прав личности при применении мер пресечения в уголовном процессе : монография. Москва : Буковед, 2007. $416 \mathrm{c}$.

5. Конвенція про права дитини: Міжнародний документ від 20.11.1989 p. URL: https://zakon.rada.gov.ua/laws/main/995_021.

6. Кучинська О.П. Домашній арешт як запобіжний захід у кримінальнопроцесуальному законодавстві. Адвокат. 2010. № 7 (118). С. 17-19.

7. Мінімальні стандартні правила Організації Об'єднаних Націй, що стосуються відправлення правосуддя щодо неповнолітніх («Пекінські правила»): Міжнародний документ від 29.11.1985 p. URL: https://zakon.rada.gov.ua/laws/show/995_211.

8. Неповнолітні, позбавлені волі відповідно до кримінального законодавства: Витяг з 24-ої Загальної доповіді Свропейського комітету з питань запобігання катуванням чи нелюдському або такому, що принижує гідність, поводженню чи покаранню. CPT/Inf(2015)1-part. URL: https://rm.coe.int/16806ccb95.

9. Пастушенко С.В. Застосування запобіжних заходів до неповнолітнього підозрюваного, обвинуваченого. Актуальні питання кримінального процесу, криміналістики та судової експертизи : матеріали міжвідом. наук.-практ. конф. (Київ, 24 листоп. 2017 р.): у 2 ч. Ч. 1. / редкол.: В.В. Чернсй, С.С. Чернявський, Л.Д. Удалова та ін. Київ : Нац. акад. внутр. справ, 2017. С. 127-129.

10. Про деякі питання здійснення кримінального провадження щодо неповнолітніх : Лист ВССУ від 18.07.2013 р. № 223-1134/0/4-13. URL: https://zakon.rada.gov.ua/laws/show/v1134740-13.

11. Про затвердження Інструкції з організації роботи підрозділів ювенальної превенції Національної поліції України : Наказ МВС України від 19.12.2017 р. № 1044. URL: https://zakon.rada.gov.ua/laws/show/z0686-18.

12. Про затвердження Інструкції про порядок виконання органами Національної поліції ухвал слідчого судді, суду про обрання запобіжного заходу у вигляді домашнього арешту та про зміну раніше обраного запобіжного заходу на запобіжний захід у вигляді домашнього арешту : Наказ МВС України від 13.07.2016 р. № 654. URL: http://zakon.rada.gov.ua/ laws/show/z1087-16.

13. Рекомендація Rec (2006) 13 Комітету Міністрів державамучасницям щодо застосування тримання під вартою, умов, у яких воно відбувається, і запровадження гарантій від зловживань з Пояснювальною запискою. Прийнята Комітетом Міністрів 27.09.2006 р. на 974-й зустрічі заступників міністрів. URL: http://khpg.org/index.php?id=1166617725. 
14. Рішення Європейського Суду з прав людини у справі «Свершов проти України» (Svershov v. Ukraine), заява № 35231/02 від 27 листопада 2008 року, URL: https://zakon.rada.gov.ua/laws/main/974_428.

15. Сівак О.В. Критерії доцільності й ефективності застосування застави як запобіжного заходу в кримінальних провадженнях щодо неповнолітніх. Вісник Запорізького національного університету. 2015. № 1 (II). C. 221-228.

16. Сівак О.В. Запобіжні заходи у кримінальному провадженні щодо неповнолітніх : дис. ... канд. юрид. наук : 12.00.09. Київ, 2016. 255 с.

17. Словник української мови : в 11 т. / АН УРСР, Ін-т мовознавства імені О.О. Потебні; редкол.: І.К. Білодід (голова) та ін. Київ : Наук. думка, 1970-1980. Т. 2 : Г-Ж. Ред. тому: П.П. Доценко, Л.А. Юрчук. 1971. 550 с.

18. Словник української мови: в 11 т. / АН УРСР, Ін-т мовознавства імені О.О. Потебні; редкол.: І.К. Білодід (голова) та ін. Київ : Наук. думка, 1970-1980. Т. 2: Г-Ж. Ред. тому: П.П. Доценко, Л.А. Юрчук. 1971. 550 с.

19. Ухвала судді Мелітопольського міськрайонного суду Запорізької області від 26.04.2017, справа № 320/1562/17-к. URL: http:// www.reyestr.court.gov.ua/Review/67335930.

20. Ухвала судді Острозького районного суду Рівненської області від 18.07.2018, справа № 567/1397/17. URL: http://www.reyestr.court.gov.ua/ Review/75353310.

Information about the authors: Fomina T. G.,

Ph.D in Law, Associate Professor, Associate Professor of Criminal Procedure and Organization of Pre-Trial Investigation Department of the Faculty № 1 Kharkiv National University of Internal Affairs 27, L. Landau avenue, Kharkiv, 61000, Ukraine

Romaniuk V. V., Ph.D in Law, Associate Professor of Criminal Procedure and Organization of Pre-Trial Investigation Department of the Faculty№ 1 Kharkiv National University of Internal Affairs 27, L. Landau avenue, Kharkiv, 61000, Ukraine 